\title{
Maternal insecurity in breastfeeding women served at a human milk bank
}

Waleska Lima Alves Simas 1

iD https://orcid.org/0000-0003-3737-2329

Jaiza Sousa Penha 2

(iD https://orcid.org/0000-0001-9805-3802

Liane Batista da Cruz Soares 3

(iD https://orcid.org/0000-0001-9548-3911

Poliana Pereira Costa Rabêlo 4

(iD https://orcid.org/0000-0003-0161-1359
Bruno Luciano Carneiro Alves de Oliveira 5

(iD https://orcid.org/0000-0001-8053-7972

Feliciana Santos Pinheiro 6

(iD https://orcid.org/0000-0001-7677-4537

1,3,5,6 Hospital Universitário. Universidade Federal do Maranhão. Rua Barão de Itapary, s.n. Centro. São Luís, MA, Brasil. CEP: 65.020-240. E-mail: waleskalasimas@gmail.com

2,4 Departamento de Enfermagem. Universidade Federal do Maranhão. São Luís, MA, Brasil.

\begin{abstract}
Objectives: to verify the prevalence and factors associated with maternal insecurity in breastfeeding with lactating women treated at a milk bank.

Methods: cross-sectional study with secondary record data from January 2017 to December 2018 at the Human Milk Bank of the University Hospital of the Federal University of Maranhão.

Results: a total of 891 lactating women were analyzed, of which $23.4 \%$ had maternal insecurity, being the second most prevalent complication. Most were young adults, married (68\%), with complete higher education (64.9\%) and family income above five minimum wages (32.5\%). Regarding the obstetric history, the highest frequency was of primigravida (63.7\%), primiparous (70\%), who had had seven or more prenatal appointments (91\%) in private health services (76.5\%) where most births also occurred (78.6\%), with cesarean section being the most prevalent mode of delivery (86.5\%), $47.2 \%$ reported never having received guidance on breastfeeding and $80.7 \%$ were breastfeeding for the first time. There was a statistically significant relationship (p-value $<0.05)$ of maternal insecurity with the place where the prenatal care was performed and the place and mode of delivery.

Conclusion: maternal insecurity was the second most prevalent breast complication among lactating women in the service. It stands out the need for adequate guidance and counseling on the subject, especially during prenatal care, contributing to avoid early weaning Key words Breast feeding, Maternal behavior, Prevalence, Milk banks, Nursing
\end{abstract}

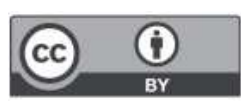




\section{Introduction}

The breastfeeding process is influenced by several factors, including the maternal aspects, especially with regard to the behavior of each woman in this context, aspects related to the child and the periods of birth and postpartum and also external conditions, which involve the environment and family routine. ${ }^{1}$

The components of the social network of the nurse, including health professionals, are capable of interfering in the decision to breastfeed, and it is relevant to pay attention to the way in which the approach to women and their families is made, because their afflictions are not always spontaneously exposed. It is recommended by WHO and the United Nations Children's Fund (UNICEF) that this approach is done in an effective way, being necessary the use of counseling skills such as qualified listening, understanding and offering help, in order to promote self-confidence and self-esteem, preparing them to deal with adverse situations and to make decisions. ${ }^{2}$

Therefore, the gestational period should not be excluded from this process, since it is generally permeated with doubts and indecision, being a moment susceptible to the emergence of feelings such as insecurity and fear. ${ }^{3}$ The prenatal consultation is an important tool in this context, because thinking about the prevention of possible intercurrences, it is the most propitious environment to promote the practice of breastfeeding and empower the future nurse. ${ }^{4}$

Maternal insecurity is generally related to a woman's perception of her ability to feed her child, being an influential factor in the decision and maintenance of breastfeeding, being also pointed out as one of the main reasons for the introduction of nutritional complementation before the baby's fourth month of life. 5

Studies point to the existence of myths and disabling beliefs about breastfeeding (BF), especially those referring to production, milk quality and the child's crying, which in general is misinterpreted and associated with hunger, configuring important representations that justify the early introduction of other foods, the supply of artificial nozzles and even the interruption of BF. 3

Following these arguments the relevance of researches focused on the factors influencing early weaning is verified, because they can subsidize the technical-scientific practice, leading to a more directed and effective action. In this sense, the objective of this study is to verify the prevalence and factors associated with maternal insecurity in breast- feeding in breastfeeding women served in a human milk bank.

\section{Methods}

This is a transversal and analytical study with a quantitative approach based on the retrospective data from the records of care that occurred between January 2017 and December 2018 at the Human Milk Bank (HMB) of the University Hospital of the Federal University of Maranhão - Maternal Infant Unit (HUUFMA-UMI - Portuguese acronym).

HUUFMA is a federal public administration agency that provides assistance, teaching, research and extension in the area of health and related areas, and is certified by the Ministry of Education and the Ministry of Health. The Maternal and Infant Unit is one of the three maternity hospitals in the state of Maranhão that has a certificate of a Friend of the Child Hospital, revalidated in 2018, and also has incentive from the Friend of the Woman Care. 6

HUUFMA's Human Milk Bank operates in the Maternal Infant Unit and has a multi-professional team to offer services for the collection and home collection of breast milk, childcare follow-up and specialized assistance to breastfeeding women, supporting mothers in the possible difficulties of breastfeeding, in addition to support and guidance. 6

The information inherent to this research was collected based on the specialized services provided to breastfeeding women. This data was recorded in specific books, with individual care forms, filled out manually by the unit's multi-professional team, containing socio-demographic information, obstetrics, main complaints or the reason for the search for assistance, diagnosis and evolution of cases, as well as information on the newborn (NB).

Thus, in order to make the collection of data possible, this form was reproduced through an instrument created on the Google Forms Platform. The information was gathered from September to November 2019 and later transcribed, generating a database with the Microsoft Excel Program.

Among all the records of specialized care that occurred during the period under investigation, those that presented the field "diagnostic hypothesis" filled with "maternal insecurity" were included. In the statistical analysis, for each aspect studied, complete records were selected, excluding those that did not meet this criterion.

The variables used for this study were: sociodemographic (age, education, marital status and family income) and obstetric (number of pregnancies, number of prenatal consultations, place of prenatal 
care, route of birth, place of delivery, number of births, guidance on breastfeeding and previous experience with breastfeeding).

For the statistical analysis, the Stata version 14 program was used, where the absolute and relative frequencies of the variables under study were estimated. Differences in characteristics associated with maternal insecurity were verified using Pearson's chi-squared test, adopting a significance level $p<0.05$. The results were presented in the format of tables and figures.

It is highlighted that this study is the result of a macro project identified as "Epidemiological Profile of the Breastfeeding women Served at a Human Milk Bank in São Luís - MA", submitted and approved in an ethical instance, via Plataforma Brasil, under CAAE n ${ }^{\circ}$ 16782719.8.0000.5086. As this is a research involving the analysis of retrospective data referring to human beings, Resolution 466/12 of the National Health Council was obeyed, having waived the use of a Free and Informed Consent Term. However, the privacy and confidentiality of patients' data was guaranteed, in order to mitigate the risks related to the secrecy.

\section{Results}

In the period proposed by the research, 891 records of specialized breastfeeding women care were analyzed in HUUFMA's HMB. Among these, maternal insecurity was present in 216 women, making up $24.3 \%$ of the sample (Figure 1), thus configuring the second highest prevalence among the intercurrences served.

Among the complaints that led professionals to raise the diagnostic hypothesis of maternal insecurity, we can highlight the reports of "little milk", "baby doesn't pick up the breast" and "baby doesn't gain weight".

Most of them were young adults, being 36\% between 30 and 34 years of age, $68 \%$ were married, $64.9 \%$ had a complete upper level and $32.5 \%$ had a family income higher than five minimum wages, no statistically significant relation being observed with any of the studied sociodemographic variables (Table 1).

Regarding obstetric variables, a higher prevalence of insecurity was observed in patients who were in their first pregnancy, corresponding to $63.7 \%$ of them; $91 \%$ made seven or more prenatal consultations, being $76.5 \%$ in private health services; $78.6 \%$ of births occurred in the same services; $70 \%$ of breastfeeding women were primiparous and $86.5 \%$ of births had a cesarean section as a delivery route

Maternal insecurity was predominant among those who reported never having received guidance on breastfeeding (47.2\%) and who were breastfeeding for the first time $(80.7 \%)$. A statistically significant relationship was identified between maternal insecurity and prenatal care $(p=0.043)$, the birth site $(p=0.001)$ and the delivery route $(p<0.029)$ (Table 2).

\section{Discussion}

The insecurity of the mother in the breastfeeding process can be revealed in the face of reports such as "poor milk", "little milk", "the baby didn't want to take the breast", "breast milk doesn't quench the baby's thirst" and "the breasts sag with lactation".1,3 The first three coincide with those of greater relevance in the classification of maternal insecurity in this study.

The users who sought specialized support in breastfeeding at the place of study, for the most part, had a reasonable socioeconomic level, belonging to class C, according to the classification of the Brazilian Institute of Geography and Statistics (IBGE - Portuguese acronym). Most services were provided to patients in private health services, a scenario that refers to the doctrinal principle of Universality of the Unified Health System (SUS Portuguese acronym), revealing the importance of HMBs as a tool for strengthening and supporting breastfeeding.

The greater frequency in the search for breastfeeding support services by women with a good socio-cultural and economic level evidenced in this study may be related to access to private health services, for both prenatal care and delivery. This may be related to the inexistence of private health units in the municipality that have IHAC certification and, therefore, the availability of adequate support for mothers in these sectors, then resorting to HMB units in search of guidance and/or interventions to the experienced intercurrences.

A recent work carried out with the HMB of a maternity clinic with a IHAC title in Belo Horizonte - MG, showed that the majority of breastfeeding women served by this unit had completed high school $(40.7 \%),{ }^{7}$ which differs from what was evidenced in this investigation. On the other hand, research conducted in a HMB in Madrid, Spain, observed that the majority of breastfeeding women $(65.3 \%)$ had university education, 8 corroborating with the results found here.

Regarding prenatal care, the investigation in 
Prevalence of insecurity in breastfeeding among breastfeeding women served $(\mathrm{N}=891)$ in a human milk bank of a university hospital, São Luís - MA, 2020.

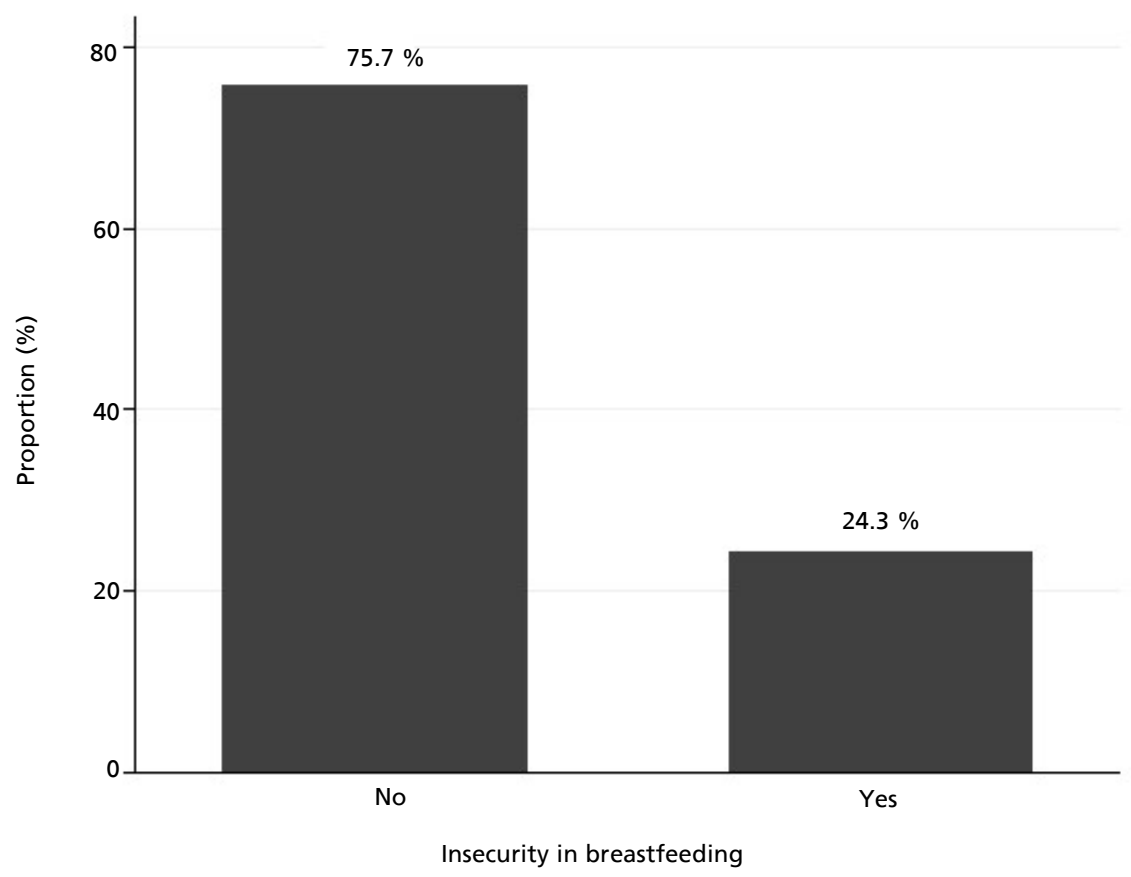

Table 1

Distribution of the women with breastfeeding insecurity according to sociodemographic variables. São Luís-MA, 2020.

\begin{tabular}{|c|c|c|c|c|c|}
\hline \multirow[t]{3}{*}{ Variables } & \multicolumn{4}{|c|}{ Insecurity in breastfeeding } & \multirow[t]{3}{*}{$p^{*}$} \\
\hline & \multicolumn{2}{|c|}{ Yes } & \multicolumn{2}{|c|}{ No } & \\
\hline & $\mathrm{n}$ & $\%$ & $\mathrm{n}$ & $\%$ & \\
\hline Age group* (years old) & & & & & 0.184 \\
\hline$<20$ & 11 & 5.1 & 36 & 5.4 & \\
\hline $20-24$ & 21 & 9.9 & 104 & 15.7 & \\
\hline $25-29$ & 53 & 24.7 & 175 & 26.4 & \\
\hline $30-34$ & 77 & 36.0 & 217 & 32.7 & \\
\hline$>35$ & 52 & 24.3 & 131 & 19.8 & \\
\hline Total & 214 & 100.0 & 663 & 100.0 & \\
\hline Marital Status** & & & & & 0.107 \\
\hline Married & 145 & 68.0 & 409 & 61.9 & \\
\hline Stable & 30 & 14.1 & 139 & 21.1 & \\
\hline Single & 38 & 17.9 & 110 & 16.6 & \\
\hline Others & 0 & 0 & 3 & 0.4 & \\
\hline Total & 213 & 100.0 & 661 & 100.0 & \\
\hline
\end{tabular}

Notes: 1- Pearson's Chi-squared Test;

$*$ Missing $=13 / * *$ Missing $=16 / * * *$ Missing $=21 / * * * *$ Missing $=48$. 


\begin{tabular}{|c|c|c|c|c|c|}
\hline \multirow[t]{3}{*}{ Variables } & \multicolumn{4}{|c|}{ Insecurity in breastfeeding } & \multirow[t]{3}{*}{$p^{*}$} \\
\hline & \multicolumn{2}{|c|}{ Yes } & \multicolumn{2}{|c|}{ No } & \\
\hline & $\mathrm{n}$ & $\%$ & $\mathrm{n}$ & $\%$ & \\
\hline Education (years)*** & & & & & 0.112 \\
\hline Incomplete Elementary School & 2 & 0.9 & 14 & 2.1 & \\
\hline \multicolumn{6}{|l|}{ Complete Elementary School/ } \\
\hline Incomplete High school & 8 & 3.8 & 35 & 5.3 & \\
\hline \multicolumn{6}{|l|}{ Complete High school/Incomplete } \\
\hline Higher Education & 64 & 30.4 & 241 & 36.6 & \\
\hline Complete Higher Education & 137 & 64.9 & 368 & 56.0 & \\
\hline Total & 211 & 100.0 & 658 & 100 & \\
\hline Income (in Minimum Wages) $* * * *$ & & & & & 0.198 \\
\hline$<1$ & 12 & 5.8 & 70 & 11.0 & \\
\hline 1 & 22 & 10.7 & 68 & 10.7 & \\
\hline $1-3$ & 50 & 24.3 & 167 & 26.3 & \\
\hline $3-5$ & 55 & 26.7 & 149 & 23.4 & \\
\hline$>5$ & 67 & 32.5 & 182 & 28.6 & \\
\hline Total & 206 & 100.0 & 636 & 100.0 & \\
\hline
\end{tabular}

Notes: 1- Pearson's Chi-squared Test;

$*$ Missing $=13 / * *$ Missing $=16 / * * *$ Missing $=21 / * * * *$ Missing $=48$.

Table 2

\begin{tabular}{|c|c|c|c|c|c|}
\hline \multirow[t]{3}{*}{ Variables } & \multicolumn{4}{|c|}{ Insecurity in breastfeeding } & \multirow[t]{3}{*}{$p^{*}$} \\
\hline & \multicolumn{2}{|c|}{ Yes } & \multicolumn{2}{|c|}{ No } & \\
\hline & $\mathrm{n}$ & $\%$ & $\mathrm{n}$ & $\%$ & \\
\hline Number of pregnancies * & & & & & 0.564 \\
\hline 1 & 137 & 63.7 & 418 & 63.2 & \\
\hline 2 & 57 & 26.6 & 162 & 24.4 & \\
\hline 3 & 12 & 5.6 & 56 & 8.4 & \\
\hline 4 or more & 9 & 4.1 & 26 & 4.0 & \\
\hline Total & 215 & 100.0 & 662 & 100.0 & \\
\hline Number of prenatal consultations ** & & & & & 0.055 \\
\hline Up to 5 & 7 & 3.3 & 37 & 5.6 & \\
\hline 6 & 12 & 5.7 & 66 & 10.1 & \\
\hline 7 or more & 191 & 91.0 & 554 & 84.3 & \\
\hline Total & 210 & 100.0 & 657 & 100.0 & \\
\hline Prenatal care location $* * *$ & & & & & 0.043 \\
\hline University Hospital & 13 & 6.4 & 69 & 11.4 & \\
\hline Another public place & 35 & 17.1 & 125 & 20.7 & \\
\hline Another private place & 156 & 76.5 & 412 & 67.9 & \\
\hline Total & 204 & 100.0 & 606 & 100.0 & \\
\hline Type of delivery**** & & & & & 0.029 \\
\hline Vaginal & 26 & 13.5 & 125 & 20.5 & \\
\hline Cesarean & 167 & 86.5 & 484 & 79.5 & \\
\hline Total & 193 & 100.0 & 609 & 100.0 & \\
\hline
\end{tabular}

Notes: 1- Pearson's Chi-squared Test;

$*$ Missing $=13 / * *$ Missing $=23 / * * *$ Missing $=80 / * * * *$ Missing $=25 / * * * * *$ Missing $=15 / * * * * * *$ Missing $=5 / * * * * * * *$ Missing $=26$. 


\begin{tabular}{|c|c|c|c|c|c|}
\hline \multirow[t]{3}{*}{ Variables } & \multicolumn{4}{|c|}{ Insecurity in breastfeeding } & \multirow[t]{3}{*}{$p^{*}$} \\
\hline & \multicolumn{2}{|c|}{ Yes } & \multicolumn{2}{|c|}{ No } & \\
\hline & $\mathrm{n}$ & $\%$ & $\mathrm{n}$ & $\%$ & \\
\hline Delivery location $* * * * *$ & & & & & 0.001 \\
\hline University Hospital & 24 & 11.4 & 99 & 15.1 & \\
\hline Another public place & 21 & 10.0 & 128 & 19.4 & \\
\hline Another private place & 165 & 78.6 & 431 & 65.5 & \\
\hline Total & 210 & 100.0 & 658 & 100.0 & \\
\hline Number of births $* * * * * *$ & & & & & 0.415 \\
\hline 1 & 163 & 77.3 & 483 & 73.9 & \\
\hline 2 & 42 & 19.9 & 140 & 21.4 & \\
\hline 3 & 6 & 2.8 & 31 & 4.7 & \\
\hline Total & 211 & 100.0 & 654 & 100.0 & \\
\hline Breastfeeding guidelines * & & & & & 0.357 \\
\hline Only during prenatal care & 22 & 10.3 & 49 & 7.4 & \\
\hline Only after delivery & 59 & 27.6 & 212 & 32.0 & \\
\hline During prenatal care and delivery & 32 & 14.9 & 109 & 16.4 & \\
\hline Never received & 101 & 47.2 & 293 & 44.2 & \\
\hline Total & 214 & 100.0 & 663 & 100.0 & \\
\hline Breastfeeding experience $* * * * * * *$ & & & & & 0.500 \\
\hline This is the first child & 171 & 80.7 & 504 & 77.3 & \\
\hline Already breastfed another baby & 38 & 17.9 & 133 & 20.5 & \\
\hline Already breastfed more than one baby & 3 & 1.4 & 10 & 1.5 & \\
\hline Without experience & 0 & 0 & 5 & 0.7 & \\
\hline Total & 212 & 100.0 & 652 & 100.0 & \\
\hline
\end{tabular}

Notes: 1- Pearson's Chi-squared Test;

$*$ Missing $=13 / * *$ Missing $=23 / * * *$ Missing $=80 / * * * *$ Missing $=25 / * * * * *$ Missing $=15 / * * * * * *$ Missing $=5 / * * * * * * *$ Missing $=26$.

Belo Horizonte showed that a small portion of the users had not performed this follow-up on a regular basis, only $1.3 \%$; more than half of those who performed it, did it in public health services, 52.4\%; and $38.8 \%$ of them reported having received guidance on breastfeeding in their consultations, 7 diverging from the results found in this survey.

In a maternity ward in Pará, certified as a IHAC and with a milk bank unit, it was found that most of the users had also done more than six prenatal consultations (77.28\%), highlighting that $59.1 \%$ of them received guidance on breastfeeding during the prenatal period, 4 an estimate that is more than double the percentage inferred in this study. This significant difference points to the fragility in offering prenatal breastfeeding guidelines to the study population.

Attention is drawn to the value of this subject, since in addition to theoretical and clinical skills, the health professionals involved need to develop communication skills, 2,10 and bearing in mind that the information on $\mathrm{BF}$ given to pregnant women during prenatal care may not be fully assimilated, leading them to make statements about the lack of knowledge on the subject. 11

This study identified a greater demand due to maternal insecurity for breastfeeding women who performed prenatal care in private health services and, although they attended six or more follow-up visits, it is known that, at the local level, these are performed by medical professionals.

In basic care, especially in the Family Health Strategy (FHS) program, pregnant women have a multi-professional approach necessary to meet the UHS integrality principle. The prenatal care of habitual risk is conducted by the nurse, following the Ministry of Health's booklet, which proposes to approach breastfeeding with the woman and her relatives, among other topics. 12

It is also important to point out that the subject is a great challenge for health professionals, since they are faced with a demand for which they have not 
been prepared and which requires sensitivity and skill in their treatment. In order to act in breastfeeding assistance, professionals must have a refined approach that goes beyond the boundaries of the biological field, understanding the lactating woman in all of the dimensions of "being a woman".13 Therefore, professional training is fundamental and must be established at technical and higher levels, in a specific and multidisciplinary manner. 14

A survey conducted in the city of Rio de Janeiro to evaluate the training of breastfeeding health professionals showed that the nursing team is endowed with best practices in relation to other professional categories. 15 Another study revealed low scores achieved by doctors and highlighted better performance of physiotherapists and nutritionists, which demonstrates the interest and commitment to promoting $\mathrm{BF}$ from other categories that compose the multi-professional team.16 In the context of breastfeeding, the health team should maintain a homogenous discourse, because discordant information can generate insecurity to the lactating woman and impair BF. 15

Other investigations on the effect of training health professionals in breastfeeding at the hospital level focused on the area of nursing, or only reached this group, due to lack of adherence of the other categories. Such findings suggest greater awareness and availability of nurses in the participation in qualifications on BF. 15 The knowledge assigned to nursing through training has positive implications for breastfeeding practice and is an important factor in supporting a mother in the decision to breastfeed. ${ }^{17}$

HUUFMA offers to the society the medium and high risk prenatal that, according to protocol, is accompanied by an obstetrician. In addition, users are offered follow-up care with other professionals. In the unit, courses are offered to pregnant women, taught by nurses, in which topics such as childbirth, puerperium, breastfeeding and newborn care are treated. However, the participation of pregnant women is not compulsory.

From the point of view of parity, primiparous women seek help in HMB more frequently, 18 which corroborates the results shown here. A study carried out in hospitals that provide childbirth assistance, in Bahia, showed that primiparity was found as one of the main factors for interruption of breastfeeding still in the first month of life. Cultural factors and beliefs in the context of the first delivery, added to the insecurity of the "first-time mother" can negatively influence the decision and the duration of breastfeeding. 19 A greater demand for specialized services by women who are experiencing their first childbirth gives the opportunity to offer greater support and guidance to this population in order to protect the EBF.

Regarding the type of birth, a high prevalence of cesarean sections in Brazil is noticeable. While at the national level the rate is $55.7 \%, 20$ in this study, an incidence of $81.2 \%$ was observed, a condition that can expose the binomial to unfavorable situations, since cesarean section has already been pointed out as one of the adverse factors to breastfeeding in the first hour of life. 21

In a research carried out at the joint housing (ALCON) of a certified IHAC hospital unit in Rio Grande do Norte, hypogalactia was listed as a reason for indicating the use of dairy supplements, and the statistical association of this variable with cesarean section type birth is evidenced.22 The association found in the present study between the insecurity of mothers regarding their ability to breastfeed and cesarean section may be related to the conception built by the woman in relation to the amount of milk produced, considering that hypogalactia is associated with the birth route in question.

Regarding the place of delivery, there was low prevalence of maternal insecurity among breastfeeding women who had their babies in HUUFMA, which can be justified by the existence of a HMB annex in the health unit's ALCON, providing specialized assistance to breastfeeding intercurrences at an early stage, taking into account the users' biopsychosocial aspects. This practice is also observed in other maternity hospitals that have milk bank units, where duly trained professionals offer support so that the difficulties in the process can be overcome already in the wards. 4

Thus, it was concluded, highlighting the prevalence of maternal insecurity among users of the service, a condition that reached almost $25 \%$ of breastfeeding women, being the second most cited breast intercurrence, and being statistically associated with the place of prenatal performance, place of delivery and route of delivery. Considering this intercurrence as a contributing factor to early weaning, it is important to point out that this perception can be avoided by means of adequate reception, information, and guidance, especially in prenatal care.

The importance of services developed in Human Milk Banks throughout the country is reiterated, acting as an important tool, constituting the UHS network, contributing to strengthening and encouraging the practice of breastfeeding, benefiting breastfeeding women, babies and their families.

We highlight the performance of health profes- 
sionals, especially the nursing team, working in a multi-professional context, in not only the services developed at HMB, but also in prenatal and puerperium, with actions to guide and encourage the practice of breastfeeding.

The results of this research are considered relevant for the scientific community and society in general, presenting data that can support the practice of health professionals and actions, beyond the local reality.

As limitations, we emphasize the scarcity of works that address maternal insecurity as an object of study, in addition to the nonexistent, incomplete or illegible data, which could not be accounted for in this analysis.

\section{References}

1. Fialho FA, Lopes AM, Dias IMAV, Salvador M. Fatores associados ao desmame precoce do aleitamento materno.Rev Cuidarte. 2014; 5 (1): 670-8.

2. Almeida JM, Luz SAB, Ued FV. Apoio ao aleitamento materno pelos profissionais de saúde: uma revisão integrativa da literatura. Rev Paulista Pediatr. 2015; 33 (3): 355 62 .

3. Marques ES, Cotta RMM, Priore SH. Mitos e crenças sobre o aleitamento materno. Revista de Ciênc Saúde Coletiva. 2011; 16 (5): 2461-8.

4. Silva YJA, Damasceno AC, Pontes CDN, Correa MQ Gurjão HHR, Lima IG, Costa FB, Carvalho RC, Nascimento RS. Dificuldades no aleitamento materno na maternidade da fundação santa casa de misericórdia do Pará e o apoio do banco de leite. Rev Eletrônica Acervo Saúde. 2019; 11 (5): 1-14

5. Marques ES, Cotta RMM, Magalhães KA, Sant'Ana LFR, Gomes AP, Batista RSA. Influência da rede social da nutriz no aleitamento materno: o papel estratégico dos familiares e dos profissionais de saúde. Ciênc Saúde Coletiva. 2010; 15 (1): 1391-1400.

6. ASCOM (São Luís). Assessoria de Comunicação do Huufma (Org.). Dia Nacional de Doação de Leite Humano mobiliza doadoras. 2018. [acesso 31 mar 2019]. Disponível em: http://www2.ebserh.gov.br/pt/web/hu-ufma/detalhesdas-noticias/-

/asset_publisher/7d2qZuJcLDFo/content/id/3142351/201805-dia-nacional-de-doacao-de-leite-humano-mobilizadoadoras.

7. Silva CM, Pellegrinelli ALR, Pereira SCL, Passos IR, Santos LC. Práticas educativas segundo os "Dez passos para o sucesso do aleitamento materno" em um Banco de Leite Humano. Ciênc Saúde Coletiva. 2017; 22 (5): 1661-7.

8. Colomina GS, Lara NG, Vieco DE, Ramón SV, Alonso EC, Pallas Alonso CR. Cracterísticas de las mujeres donantes de um banco de leche materna y relacíon com el tiempo de

\section{Authors' contributions}

Simas WLA contributed in the design of the project, literature review, collection and construction of the database, writing and reviewing the manuscript. Penha JS contributed in the collection, analysis and construction of the database and in the review of the manuscript. Soares LBC contributed in the conception and coordination of the project, data interpretation and manuscript review. Rabêlo PPC contributed in data interpretation, writing and critical review of the manuscript. Oliveira BLCA contributed in the construction of the database and statistical analysis of results. Pinheiro FS contributed to the review and final approval of the text. All authors approved the final version of the manuscript.

donacón. Anales de Pediatría. 2014; 80 (4): 236-41.

9. Boccolini CS, Boccolini PMM, Monteiro FR, Venâncio SI, Giugliani ERJ. Tendência de indicadores do aleitamento materno no Brasil em três décadas. Rev Saúde Pública. 2017; 51: 1-9.

10. Caminha MF, Serva VB, Anjos MM, Brito BB, Lins MM, Batisto FM. Exclusive breastfeeding among profissionals in a family healthcare program. Cienc Saude Coletiv. 2011; 16: $2245-2250$

11. Silva NM, Waterkemper R, Silva EF, Cordova EP, Bonilha ALL. Conhecimento de puérperas sobre amamentação exclusiva. Rev Brase Enferm. 2014; 67 (2): 290-95.

12. Rocha AC, Andrade GS. Atenção da equipe de enfermagem durante o pré-natal: percepção das gestantes atendidas na rede básica de Itapuranga-GO em diferentes contextos sociais. Rev Enferm Contemporânea. 2017; 6 (1): 30-41.

13. Araújo RM, Almeida JA. Aleitamento materno: o desafio de compreender a vivência. Rev Nutr. 2007; 20 (4): 431-8.

14. Hoddinott P, Pill R, Chalmers M. Health professionals, imple-mentation and outcomes: reflections on a complex interventionto improve breastfeeding rates in primary care. Fam Pract. 2007: 84-91

15. Jesus PC, Oliveira MIC, Moraes JR. Capacitação de profissionais de saúde em aleitamento materno e sua associação com conhecimentos, habilidades e práticas. Ciênc Saúde Coletiva. 2017; 22(1): 311-20.

16. Cavalcante AVSON, Borges EM, Araújo AGF, Medeiros LNB, Melo LGNS. Avaliação dos conhecimentos e práticas em aleitamento materno dos profissionais de saúde em um hospital amigo da criança. Rev Bras Educ Saúde. 2019; 9 (2): $13-20$.

17. Watkins AL, Dodgson JE. Breastfeeding educational interventi-ons for health professionals: a synthesis of intervention studies. J Spec Pediatr Nurs. 2010; 15 (3): 223-32. 
18. Ferreira LB, Nea ITO, Sousa TM, Santos LC. Caracterização nutricional e sociodemográficas de lactantes: uma revisão sistemática. Ciênc Saúde Coletiva. 2018; 23 (2): 437-48.

19. Martins CC, Vieira GO, Vieira TO, Mendes CMC. Fatores de risco maternos e de assistência ao parto para interrupção precoce do aleitamento materno exclusivo: Estudo de coorte. Rev Baiana Saúde Coletiva. 2011; 35 (1): 167-78.

20. Freitas PF, Moreira BC, Manoel AL, Botura ACA. O parecer do Conselho Federal de Medicina, o incentivo à remuneração ao parto e as taxas de cesariana no Brasil. Cad Saúde Pública. 2015; 31 (9): 1839-55.
21. Belo MNM, Azevedo PTACC, Belo MPM, Serva VMSBD, Batista Filho M, Figueiroa JN, Caminha MFC. Aleitamento materno na primeira hora de vida em um Hospital Amigo da Criança: prevalência, fatores associados e razões para sua não ocorrência. Rev Bras Saúde Materno Infantil 2014; 14 (1): 65-72.

22. Pinheiro JMF, Menêzes TB, Brito KMF, Melo ANL, Queiroz DJM, Sureira TM. Prevalência e fatores associados à prescrição/solicitação de suplementação alimentar em recém nascidos. Rev Nutrição. 2016; 29 (3): 367-75.

Received on April 20, 2020

Final version presented on November 12, 2020

Approved on December 28, 2020 